\title{
Doğanın Dönüştüren Gücü: Aşk Romanları Okuyan İhtiyar ve Canavarlar Kenti Adlı Eserlerin Ekoeleştirel Değerlendirilmesi
}

\author{
Burcu Tekin ${ }^{\mathrm{a}, \mathrm{b}}$
}

Özet

Çalışmanın amacı, Latin Amerika Edebiyatı'nın önemli isimlerinden Şilili yazar Luis Sepúlveda'nın kaleme aldığı Aşk Romanları Okuyan İhtiyar ve Isabel Allende'nin genç okurlara yönelik yazdığı Canavarlar Kenti adlı eserlerin ekoeleştirel değerlendirilmesinin yapılmasıdır. Çalışmada öncelikle doğa ve insan ilişkisinin, çevre ve edebiyat etkileşiminin ve ekoeleştiri kavramının genel hatlarıyla açıklanması planlanmıştır. Kuramsal kısmın çözümlenmesinin ardından her iki eserden de alınan çeşitli durum ve olaylara ait örneklerle ekoeleştirel bağlamda doğanın dönüştüren gücünün karakterler üzerinden aktarımına dikkat çekilmesi hedeflenmiş, çevresel farkındalığın ve çevre bilincinin önemi vurgulanmaya çalışılmıştır.
Anahtar Kelimeler

Latin Amerika Edebiyatı Isabel Allende Luis Sepúlveda

Ekoeleştiri

Makale Hakkında

Geliş Tarihi: 13.12.2018

Kabul Tarihi: 25.12.2020

Doi: 10.18026/cbayarsos.496700

\section{Transformative Power Of Nature: An Ecocritical Analysis Of The Old Man Who Read Love Stories And City Of The Beasts}

\begin{abstract}
The purpose of this study is to offer an ecocritical analysis of the works The Old Man Who Read Love Stories by Luis Sepúlveda, an eminent Latin American author and City of the Beasts by Isabel Allende, written for young readers. In the study, first it is aimed to explain the relationship between natural environment and human, the interaction between literature and nature and ecocriticism in a broad sense. After the theoretical analysis, various exemplary situations from both books will be presented and the transformative power of nature will be exemplified through events and characters and an emphasis will be given to environmental awareness and environmental consciousness.
\end{abstract}

Keywords

Latin American Literature Isabel Allende Luis Sepúlveda

Ecocriticism

\begin{tabular}{r} 
About Article \\
\hline Received: 13.12 .2018 \\
Accepted: 25.12 .2020 \\
Doi: $10.18026 /$ cbayarsos.496700
\end{tabular}

Doi: $10.18026 /$ cbayarsos.496700 


\section{Giriş}

İnsan doğduğu andan itibaren fiziksel ve duygusal anlamda gelişim ve dönüşüm içindedir. Yaşamı boyunca aslında kim olduğunu arar ve olasılıklar arasında toplum içinde kendini konumlandırmaya çalışır. Bu arayışta kişinin kendiyle olan ilişkisinin yanı sıra çevresiyle olan iletişimi ve etkileşimi de önem kazanır. Bireyin kendini sevmesi, kendine değer vermesiyle çevresine verdiği değer eş zamanlı ilerler. Birey kendini tanımaya, anlamaya yerküreyle bir bütün olarak yaşamanın önemini kavramaya başladığında benmerkezci düşünce yapısını bırakır. Bu durum hem bireyin farkındalığının gelişmesine, hem de çevre bilinci kazanmasına yardımcı olur.

Dünyanın geleceğini tehdit eden ekolojik sorunların çözümü için disiplinlerarası çalışmalar giderek önem kazanmaktadır. Bu çalışmaların öncüllerinden biri sayılan ve yayımlandığı dönemde (1962 yılında) oldukça ilgi çeken Rachel Carson'ın Sessiz Bahar' 1 , çevreci hareketin ve çevre bilincinin gelişimi açısından okunması gereken temel kaynaklar arasındadır. Yazgünoğlu (2018) Sessiz Bahar'ı şu şekilde yorumlar: “Carson çevresel kirliliğin geri dönülmez tahribat yarattığını vurgularken pestisit gibi kimyasalların öldürücü yönünü hem bilimsel hem de belgesel olarak Sessiz Bahar'da sunar" (ss. 67-68). Kitap, Dünya'nın yeşil pelerini olarak adlandırdığı bitkilerin, suyun ve toprağın önemine dikkat çekmektedir. İnsan kaynaklı tahribat ve kimyasal madde kullanımı sonucunda doğaya verilen zarar anlatılmıştır (Carson, 2011). Bu açıdan değerlendirildiğinde doğadaki olayların edebiyata yansımasını konu alan ve dünyadaki tüm varlıkların birbirleriyle etkileşimini insan merkezli olmayan bakış açısıyla inceleyen ekoeleştiri öne çıkmaktadır.

Çalışmada, Luis Sepúlveda'nın Aşk Romanları Okuyan İhtiyar adlı eserinin ve Isabel Allende'nin genç okurlara yönelik kaleme aldığ Canavarlar Kenti adlı eserinin ekoeleştirel değerlendirilmesi hedeflenmektedir. Her iki eserde de doğayla uyum içinde yaşamanın önemi ve insan kaynaklı doğa tahribatı nedeniyle oluşan olumsuzlukların sonuçları vurgulanmıştır.

Öncelikle, genel çerçevede çevre ve doğa algısının incelenmesi, ekoeleştirinin açıklanması ve gelişiminin anlatılması amaçlanmıştır. İlerleyen bölümlerde, aktarılan bilgiler ışığında her iki eserin konuya ilişkin örnekler ekseninde detaylı bir şekilde yorumlanması planlanmıştır.

\section{Genel Hatlarıyla Çevre, Doğa ve İnsan Etkileşimi}

Çevre sözcüğü, çeşitli bakış açılarına göre değişiklik göstermektedir. Keleş (2015) çevrenin dar ve geniş olarak değerlendirilen çeşitli tanımları olduğunu şu şekilde ifade eder (s.19): “Dar anlamda çevreden, canlıların yaşamlarını sürdürdükleri ortam anlaşılmaktadır. (...) Geniş anlamda, canlı yaşamını etkileyen tüm etmenler çevreyi oluşturan öğeler durumuna gelmektedir. Hem canlı (biyotik çevre) hem de cansız varlıklar (abiyotik) çevre kavramının içindedir" ( s. 19). Dünya' da yaşamın sağlıklı bir şekilde sürdürülebilmesi için insan ve çevre arasındaki etkileşimin bilinçli bir şekilde yürütülmesi, doğa dengesinin sağlanması, canlı ve cansız varlıklar arasındaki ilişkinin öneminin kavranmasına ve anlaşılmasına bağlıdır (Akın, 2017, s. 46). Toska'ya göre (2017) “İnsan yaşamını sürdürebilmek için kendisi dişında varlıklara duyduğu ihtiyaçtan dolayı doğa ile her zaman etkileşim, iletişim ve ilişki içinde olmuştur. Bu ilişkinin uyumlu bir şekilde yürütülmesi, doğanın belirleyip verdiği izinler çerçevesinde gerçekleşmesine bağlıdır. Bu çerçeveye bağlı kalınarak doğal döngü içerisinde doğa ile insan birbirine zarar vermeden varlıklarını sürdürebilirler"( s. 15). Fakat bir yanda çevre bilincine sahip, duyarlı insanlar varken, diğer yanda yerkürenin kaynaklarını sınırsızca 
ve sadece kendi menfaati için kullanabileceğini düşünen benmerkezci düşünce yapısına sahip insanlar da bulunmaktadır. Özdağ (2017) bu durumu şu şekilde özetler:

\footnotetext{
“Günümüzde insanın doğaya verdiği zarar şimdiye kadar görülmemiş boyutlardadır. İnsan faaliyetleriyle ormanların yok olduğunu, nehirlerin kuruduğunu, su kaynaklarının kirlediğini, doğadaki biyolojik zenginliğin her geçen gün kaybolduğunu okuyor ve görüyoruz; iklim değişikliği, toprak erozyonu, zehirli atıklar, asit yağmurları gibi tehlikelerin dünyayı gittikçe daha fazla tehdit ettiğine şahit oluyoruz" (s. 19).
}

Bu bilinç yapısına bağlı kaotik durum ancak çevre merkezli bakış açısının benimsenmesiyle olumlu yönde değişebilir. Bu değişim ve dönüşümün gerçekleşmesinde ekolojinin biyomerkezci yaklaşımı ve yeryüzündeki tüm canlı ve cansız varlıkların birbiriyle bağlantısının önemi ortaya çıkıyor (Özdağ, 2017, s. 19). Bu noktada ekolojinin tanımını açmak gerekiyor: "Ekosistem, ekolojik denge gibi kavramlarla kullanılan ekoloji, Buffon, Humboldt, Darwin gibi pek çok bilim insanınca da daha önce kullanılmış olmasına karşın, ilk kez 1866 yılında, Ernest Haeckel tarafından canlılarla yaşadıkları ortam arasındaki ilişkileri inceleyen bir bilim dalı olarak tanımlanmış olduğu genelde kabul görmektedir"(Keleş, 2015, s. 21). Sosyal ekoloji kavramının yaratıcılarından, siyaset felsefecisi Murray Bookchin (2017) ekolojiyi şu şekilde tanımlar:

\footnotetext{
"Ekoloji, bana göre, doğa ve insanlığın doğal dünyayla ilişkisi hakkında daha geniş bir kavrayış getirir; biyosferin dengesini ve bütünlüğünü kendinde bir amaç olarak görür. Doğal çeşitlilik, yalnızca ekosistemi oluşturan bileşenler ne kadar çeşitli olursa, ekosistemin o kadar istikrarlı olacağından dolayı değil; çeşitliliğin kendi başına güçlü bir canlı evren nosyonunun parçası olarak bağrımıza basmamız gereken bir değer olmasından dolayı da geliştirilmelidir" (s. 86).
}

Ekolojide, ekosistem içindeki parçaların teker teker incelenmesi yerine biriyle ilişkilerine bakılmasının gerekliliği öne çıkmaktadır. Son yıllarda ekolojinin bütünsel yaklaşımı, çevresel farkındalık ve çevre bilinci çeşitli disiplinler sayesinde insanlara ulaştırılmaya çalışılıyor. Çevrebilimci olan Kışlaoğlu ve Berkes (2017) Çevre ve Ekoloji adlı kitaplarında günümüz ekolojisini diğer bilim dallarından ayıran en önemli ve etkin özelliğin bilimsel yöntem kullanımı açısından bütünsel yaklaşım olduğunu ifade etmektedirler (s. 38).

\section{Çevre ve Edebiyatın Buluşması: Ekoeleştiri}

İstisnalar olsa da günümüzde insanların büyük bir çoğunluğu doğayla uyum içinde yaşamak, bütünün bir parçası olmak ve sade bir yaşam sürmek yerine kendilerini doğanın hâkimi olarak konumlandıran bencil bakış açısına sahipler. Doğayı sadece "yeşillik" olarak benimseyenler, yıllardır süregelen ve dünyanın geleceğini de etkileyecek olan ekolojik sorunlarla yüzeysel şekilde ilgilenmişlerdir. Bu noktada ekoeleştiri displinlerarası bir yaklaşım olarak devreye girmektedir. Kendini dünyanın merkezine koyan ve kendinden başka hiçbir varlığ düşünmeyen insanları ekolojik sorunlara dikkat çekerek insanlara farkındalık kazandırmayı hedefleyen ekoeleştirinin ilk tanımı Cheryll Glotfelty'nin 1996 yılında Harold Fromm'la derlediği The Ecocriticism Reader adlı kitabının giriş bölümünde yapılmasına rağmen terimsel bağlamda ilk kullanımı 1978 yılında William Rueckert'in Literature and Ecology adlı makalesinde yer almıştır (Oppermann, 2012, s. 10). Rueckert (1996) ekoeleştiri kavramını edebiyat alanına uyarlanışı olarak değerlendirmiş, aynı zamanda yeryüzündeki her şeyin birbiriyle olan bağlantısına da dikkat çekmiştir (s. 107-108). 
Glotfelty'e (1996) göre "ekoeleştiri edebiyat ve fiziksel çevre arasındaki ilişkinin incelenmesidir" (s. xvii). Ekoeleştiri üzerine çalışmalarını sürdüren Garrard (2016) için ise ekoeleştiri “(...) en geniş tanımıyla, insanla insan dışı arasındaki ilişkinin insanlığın kültürel tarihi boyunca incelenmesi ve bizzat insan kavramının eleştirel bir incelemesidir" (s. 17). Oppermann'a (2012) göre "ekoeleştiri, edebiyat eleştirisi ve kuramları içinde, edebiyat ve kültür metinlerini çevreci bir bakış açısıyla yorumlayan, edebiyat ile çevre, ekoloji ile kültür arasındaki ilişkileri inceleyen tek akımdır. Ekoeleştiri, bozulan ekolojik dengelerin sosyal ve kültürel etkilerini sosyo-kültürel bağlamda incelemektedir"(s. 9). Bu nedenle ekoeleştiri çevre bilimiyle ilişkisi açısından kültür ve edebiyat akımları içerisinde çok özel bir konumdadır. Ekoeleştiride insan ve doğa birbirinden ayrı değerlendirilmez, doğada bulunan her şeyin birbiriyle bağlantılı olduğu belirtilir ve yaşamın ancak bütünsel bir dengeyle sağlıklı bir şekilde sürebileceği ifade edilir. Bu evrensel dengeye verilen zarar tüm ekosistemi kolayca etkiler. 1990'lı y1llardan günümüze kadar ekoeleştirinin üç evreden geçtiğini belirtmek gerekir (Oppermann, 2012, s. 17). Ergin ve Dolcerocca (2016) ekoeleştirinin başlangıç dönemini şu şekilde yorumlarlar:

\footnotetext{
“Başlangıç aşamasında ekoeleştiri İngiliz Edebiyatı ve Amerikan çalışmalarının bir uzantısı olarak ortaya çıktı̆̆ından ilk evrede yapılan akademik çalı̧malar yoğunluklu olarak Amerikan doğa yazını, İngiliz pastoral anlatımlar, Romantik akımı ve Derin Ekoloji hareketine odaklanır. 1990'ların başında yayınlanan pek çok kitap Henry David Thoreau, John Muir, Edward Abbey ve Aldo Leopold gibi realist anlatıma başvuran Amerikalı yazarları öne çıkarı"' ( s. 300).
}

Lawrence Buell ekoeleştirinin ilk dönemini birinci dalga olarak değerlendirmiş ve ekoeleştirinin ilk dalgada Amerikan Edebiyatı'nda ekolojik farkındalık yarattığını belirtmiştir. $\mathrm{Bu}$ dönemde ekoeleştirinin gelişimine önemli bir ölçüde katkıda bulunan Arne Naess'in geliştirdiği Derin Ekoloji akımı ekoleştirinin kök salmasında ve mistik boyutunun gelişiminde önemli bir yere sahiptir. Buell'in ikinci dalga olarak nitelendirdiği ekoeleştirinin ikinci evresi ilk dönemki anlayışa eleştirel yaklaşmış ve çevre kavramını boyutsal bağlamda genişleterek kültürel ve sosyal çevre bilincini de konuya dâhil etmiştir. Michael Bennet ve David W. Teague tarafından yazılan The Nature of Cities: Ecocriticism and Urban Environments ve John Tallmadge ve Henry Harrington tarafından derlenen Reading Under the Sign of Nature: New Essays in Ecocriticism bu dönemin ilgi çeken çalışmaları arasındadır. Ekoeleştirinin üçüncü evresinde ise sömürgecilik sonrası edebiyat, kültür çalışmaları, sınıf ve cinsiyet üzerine geliştirilen ekolojik temelli yaklaşımlar, biyoetik, biyosemiyoloji ve biyoteknolojiler posthümanizmle ortaya çıkan yeni ve farklı açlımlarla etkileşim içine girmiştir. Graham Huggan ve Helen Tiffin'in birlikte kaleme aldıkları Postcolonial Ecocriticism: Literature, Animals, Environment adlı çalışma bu dönemin öne çıkan anlatıları arasındadır. (Buell'den aktaran Oppermann, 2012, ss. 20-26). Görüldüğü üzere farklı dönemlerden geçen, gelişmeye ve dönüşmeye devam eden ekoeleştirinin temel amaçlarından biri bireye çevresel bakış açısı ve farkındalık kazandırmaktır. Çevresel bakış açısı, bireye "doğada meydana getirdiği değişiklikleri gösterecek yani ona çevresiyle olan ilişkisini gösteren bir ayna tutacaktır" (Arıkan, 2011, s. 47). Böylelikle insan ve çevresi arasındaki derin bağın önemi ortaya çıkacaktır. Disiplinlerarası bir yaklaşım olması nedeniyle pek çok alandan konuyla ilgilenenleri bir araya toplayan ekoeleştiri edebi metinlerin yorumlanmasında etkili bir kaynaktır. Yazarlar bir yandan eserleri aracılığıyla ekosistemdeki dengenin insanlar tarafından bozulması sonucu yaşanan olumsuzlukları farklı kurgular aracılığıyla anlatırlarken bir yandan da eserlerinde geçen hikâyeler ve karakterler vasıtasıyla okurun çevre bilinci 
edinmesini sağlamaktadırlar. Böylelikle doğadan bir anlamda kopan, uzaklaşan veya doğaya yabancılaşan birey de doğayla ilişkisini gözlemleyebilmektedir.

\section{Aşk Romanlan Okuyan İhtiyar ve Canavarlar Kenti'nin Ekoeleştirel Yorumlanmasi}

Şilili çevreci yazar Luis Sepúlveda'nın kaleme aldığı̆, pek çok dile çevrilen ve birçok ödül alan Aşk Romanları Okuyan İhtiyar adlı eseri Latin Amerika Edebiyatı'nda ${ }^{1}$ çevre bilincinin yerleşmesinde öne çıkan anlatılar arasındadır. Amazon'un derinliklerinde El Idilio köyünde yaşamına devam eden, gününü aşk romanları okuyarak geçiren Antonio José Bolívar Proaño'nun bir jaguarın peşine düşmesiyle ormanda yaşadığı serüven ve bu süreçte kendisiyle yüzleşmesi anlatılmaktadır. Sepúlveda gibi Şilili olan, Latin Amerika Edebiyatı'nın önde gelen yazarlarından Isabel Allende genç okurlara çevresel farkındalık kazandırmaya yönelik kaleme aldığ ${ }_{1}$ Canavarlar Kenti'nde ise annesinin hastalığı nedeniyle babası tarafından büyükannesinin yanına gönderilen Alexander Cold'un büyükannesiyle beraber Amazonlar'da yaşadığ 1 düşünülen bir canavarın peşine düşmesi ve bu süreçte hem çevresel farkındalık geliştirmesi hem de kendini gerçekleştirme yolculuğu anlatılmıştır. Eserlerde her iki yazar da çevre bilincinin gerekliliğine dikkat çekmiş, bu durum da eserin odak noktasını oluşturmuştur. Aşk Romanları Okuyan İhtiyar adlı eserde altın arayıcılarının ve avcıların uğrak yeri olan El Idilio tüm olayların çıkış noktasını oluşturan yerleşim birimidir. Kitabın ilk satırları senede iki defa El Idilio'ya Sucre adlı tekneyle uğrayıp köy sakinlerinin diş problemleriyle ilgilenen huysuz diş hekimi Rubicundo Loachamín'in öfkesiyle başlar. Loachamín eserde her türlü otoriteye karşı duran bir figür olarak ifade edilir. Doğa, Loachamín' in saldırgan tavrıyla eş zamanlı şu şekilde sesini duyurur:“Gri bulutlar, şiş bir eşek göbeği gibi tehditkâr bir tavırla insanların başlarının birkaç karış üstünde asılı duruyordu. Ilık ve yapışkan rüzgâr yerdeki yaprakları dört bir yana savuruyor, belediye binasının önünü süsleyen bodur muz ağaçlarını şiddetle sallıyordu" (Sepúlveda, 2017, s. 13). Eserde doğa Loachamín'in duygularını yansıtmaktadır ve adeta onu aynalamaktadır. Canavarlar Kenti'nde de olay örgüsü annesi hasta olan ve bu gerçekle yüzleşmekte zorlanan Alexander Cold'un gördüğü rüya ile başlar. Yazar, Alexander Cold'un üstesinden gelemediği bu durumu doğa olaylarından yararlanarak şu şekilde ifade eder:

\footnotetext{
“Rüyasında, kocaman kapkara bir kuşun pencereye çarparak paramparça olan camların şangırtısı arasında evin içine girdiğini ve annesini alıp götürdüğünü görmüştü. Dev gibi bir akbabanın sarı renkli pençeleriyle Lisa Cold'u yakalayıp içeri girdiği kırık pencereden nasıl dışarı çıtığını ve yoğun, kapkara bulutlarla kaplı gökyüzünde nasıl yitip gittiğini çaresizlikle izliyordu. Fırtınanın gürültüsü, ağaçları kamçlayan rüzgârın, çatıdaki yağmurun, şimşeklerin ve gök gürültülerinin sesi uyandırmıştı oğlanı" (Allende, 2016, s. 9 ).
}

Aşk Romanları Okuyan ihtiyar'da olaylar Antonio José Bolívar Proaño etrafında gelişir. Antonio José Bolívar Proaño ve diş hekimi konuşurlarken yavaş yavaş yaklaşan ve içinde sarışın erkek cesedinin olduğu kanoyu farkederler. Bu süreçte belediye başkanı da orada bulunmaktadır ve kanodaki cesedin sorumlusu olarak Amazon yerlilerinden Shuarlar ${ }^{2}$ olduğunu iddia etmektedir. Shuarlar bu duruma karşı çıkmalarına rağmen belediye başkanı onları suçlamaya devam etmektedir. Bu fikir karmaşası sırasında Antonio José Bolívar cesedin üzerinde bulunan kesiklerin bir jaguar tarafından yapıldığını belirtmesine rağmen belediye başkanı ısrarla adamın Shuarlar tarafından öldürüldüğünü diretmektedir. Cesedi dikkatli bir şekilde inceleyen Antonio José Bolivar bu duruma şu şekilde açıklık getirir: “Dişi jaguar tarafından öldürülmüş. Erkek şayet yaralıysa yakınlarda olmalı. Dişi jaguar adamı öldürmüş, başka hayvanlar kurcalamasın diye üstüne işeyip işaretlemiş ve eşini aramaya gitmiş" (Sepúlveda, 
2017, s. 25). Belediye başkanı ihtiyarın sözlerine inanmaz ve "vahşiler" olarak adlandırdığ Shuarlar'ın, adamı soymak için öldürdüklerini yineler. Eserde bu durum şu şekilde ifade edilmektedir: "Kocakarı masalları bunlar. Bu vahşiler adamı öldürüp üstüne kedi çişi dökmüşler. Sizler de her zırvayı yutuyorsunuz (Sepúlveda, 2017, s. 25). Cesedin üzerinden çıkan cüzdan ve saat, belediye başkanının dediklerini çürütür niteliktedir. Ayrıca, adamın sırt çantasından saçma fişekleri ve beş adet tuzlanmış yavru jaguar kürkü de çıkmıştır. Avcının para uğruna jaguar yavrularını gözünü kırpmadan öldürmesi kendi sonunun da başlangıcıdır.

Bu bölümde Sepúlveda, günümüz insanının genelinde bulunan bencilliği ve kendini doğanın hâkimi sayarak canı istediğine istediği gibi davranmasının olası sonucunu okuyucuya sunar ve hayvan türlerinin yok olmasının sebeplerinden birinin de bilinçsiz insan davranışı olduğunu vurgular. Ergin Zengin (2018) İnsan-Merkezciliğin Yükselişi: Avcı-Toplayıcılıktan Günümüze Hayvanın Değişen Statüsü adlı makalesinde insanın kendisini hayvanlardan üstün görmesini ve onlara hükmetme arzusunu şu şekilde yorumlar: “ Türcülük, insan-merkezcilik gibi farklı etiketlerle adlandırılan bu yaygın ideoloji, yılda trilyonlarca hayvanın sömürülmesini ve öldürülmesini meşru kılan bir zemin hazırlamakta; insanın hayvandan üstün olduğu düşüncesini normalleştirmektedir" (s. 143). Araştırmacı, makalenin sonuç kısmında insanın kendisini doğadan ve hayvanlardan daha üstün görme yaklaşımından uzaklaşmasının yolunun insan merkezli bakış açısından kurtulmakla başladığını belirtir ve sözlerine şu şekilde devam eder: "Alışkanlıklarımız etrafında normalleştirdiğimiz öldürme ve sömürme eylemlerini sorgulayarak, hayvanların tıpkı bizler gibi acıdan uzak bir yaşam sürdürme haklarının olduğunu kabul ederek, hayvanları da ahlaki sorumluluk alanımıza dahil etmeliyiz. Bunu yapabilmenin yolu, insanın da hayvanın da aynı gökyüzü altında yaşam mücadelesi veren yoldaş türler olduğunu, hepimizin dünyalılar olduğunu görebilmekten geçer" (Ergin Zengin, 2017, s. 161).

Eserde belediye başkanın yerlileri küçümsemesi, onları vahşiliğin ve yabaniliğin bir simgesi olarak değerlendirmesi, avcının düşüncesiz tavrı sonrasında olanlar şu sözlerle ifade edilir:

\footnotetext{
“Sahneyi gözünüzde canlandırın. Dişi, yağmurun ilk haftalarında karnını doyurmak ve yavrularnı emzirebilmek için ava çıkmak zorunda kalıyor. Yavrular henüz sütten kesilmediğinden erkek onları korumak için yanlarında kalıyor. Hayvanlar böyle şeyler yaparlar. Gringo da onları gafil avlıyor. Dişi acıdan delirmiş bir halde dört dönmeye başlıyor. Adamın peşine düşüyor" (Sepúlveda, 2017, s. 26).
}

Bolívar'ın haklı öfkesi şu sözlerle devam eder: "Şu kürklere bakın. Küçücükler, hiçbir işe yaramazlar. Yağmurda ava çıkılır mı hiç? Hem de saçmayla! Bakın kürkler delik deşik olmuş. Anlıyor musunuz? Siz Shuarları suçladınız ama yasaları asıl çiğneyenin gringo olduğu ortaya çıktı. Herif av mevsimi dışında avlandığı yetmiyormuş gibi bir de av yasağı olan hayvanları öldürüyormuş" (Sepúlveda, 2017, s. 25).

Sepúlveda, bu olayın ve Bolívar'ın haklı tepkisinin ardından eserde Antonio José Bolívar Proaño'nun geçmişini ve çevre bilincinin oluşmasında deneyimlediklerini okurla paylaşır. Bolívar'ın hayatı oldukça zorlu geçer. Eşi Dolores Encarnación del Santísimo Sacramento Estupiñán Otavalo'yla, Imbabura Yanardağı'nın yakınındaki San Luis adlı köyde çocukken tanışır ve daha reşit değillerken evlendirilirler. Maddi zorlukların yanı sıra Dolores' in hamile kalamaması nedeniyle toplum tarafından dışlanırlar. Bu nedenle köyde kalmak istemezler ve Amazon' da kurulacağını duydukları yeni bir yerleşim bölgesine gitmek için köyden ayrılırlar. Uzun bir yolculuktan sonra El Idilio'ya gelirler. Eşiyle beraber derme çatma bir baraka inşa ederler ve ormanlık araziyi temizlemeye başlarlar (Sepúlveda, 2017). Yazar, daha çevre 
bilincinin gelişmediği Bolívar ve eşi Dolores'in doğaya üstün gelme çabasının anlamsız sonucunu şu şekilde aktarır:

\begin{abstract}
“Şafak vaktinden günbatımına kadar çalışıp didinerek bir ağacı ve birkaç sarmaşıkla bitkiyi yerlerinden sökmüşler ama ertesi gün şafak söktügünde bitkilerin intikam alırcasına bir şevkle yeniden büyüdüğünü görmüşlerdi. Yağmur mevsiminden ilki gelip çattığında erzakları tükenmişti ve ne yapacaklarını bilemez haldeydiler. Kimi yerleşimciler eski tüfeklerle silahlanmıştı, fakat ormandaki hayvanlar hızlı ve kurnazdı. Nehirdeki balıklar bile bir türlü yakalanmıyor, üstelik onlarla dalga geçercesine önlerinde sıçrayıp duruyorlardı"(Sepúlveda, 2017, s. 25).
\end{abstract}

Alıntıdan da anlaşılacağı üzere, gezegenimizdeki her ekosistemin kendi içinde bir bütünlüğü vardır. Ekosistem dışından bir gücün gelip sırf kendi çıkarı için ormanı şekilden şekle sokma isteği büyük bir hatadır ve bütünün asla dengesi bozulmamalıdır. Her şey doğal akışında ve olduğu gibi bırakılmalıdır. Bu durum yorumlandığında Bolívar ve eşinin doğa üzerinde hâkimiyet kurma çabasının boşunalığı öne çıkar. İnsan merkezli bakış açısının olası sonuçlarını yaşarlar. Yerleşimcilerin doğaya bilinçsiz bir şekilde yaklaştıklarını gören Shuar yerlileri Bolivar ve eşi gibi pek çok yerleşimciye ormana uyum sağlamaları konusunda yardım ederler. Eserde Shuar yerlilerinin yaklaşımı şu şekilde aktarılır: "(...) bunlar Shuar yerlileriydi; yerleşimcilerin haline acımış ve onlara yardım eli uzatmaya gelmişlerdi. Yerleşimciler avlanmayı, balık tutmayı, fırtınalara dayanıklı sağlam barakalar inşa etmeyi, yenilebilir meyveleri zehirlilerinden ayırt etmeyi, en önemlisi de ormanla uyum içinde yaşamayı hep onlardan öğrenmişlerdi" (Sepúlveda, 2017, s. 37). Eserde görüldüğü üzere yerli halk Shuarlar ile bölgeye sonradan göç edip yerleşenler doğaya karşı iki farklı yaklaşım sergilemektedirler. Shuarlar doğayı olduğu gibi kabullenirken, yerleşimciler doğanın mevcut dengesini korumak yerine doğaya hüküm sürme arzusundadırlar.

Bolívar'ın eşi Dolores ikinci senelerinde sitmaya yakalanıp ölür ve eski köyüne dönemeyeceğini düşünen Bolívar, ormandaki hayatına tek başına devam etmeye başlar. Eşinin ölümünden duyduğu üzüntü ilk günlerde ormana önyargıyla yaklaşmasını tetikler. Fakat bir süre sonra yerli halkın dilini öğrenir, onlarla beraber doğayı keşfetmeye başlar. Ormanı keşfettikçe doğaya olan saygısı artar, karakteri doğayla bütünleşir. Doğaya karşı bakış açısının değişmesinden dolayı davranışlarında da değişimler gözlenir. Yazar, Bolívar'ın yavaş yavaş oluşturduğu çevre bilincini şu şekilde tasvir eder:

\footnotetext{
“O zamana dek özgürlük denen sözcüğe kafa yormayan Antonio José Bolívar Proaño, ormandaki özgürlüğün tadını doya doya çıkarıyordu. Nefretini ne kadar canlı tutmaya çalışsa da bu dünyadan keyif almadan edemiyordu; böylece sınırları ve efendileri olmayan bu mekânın çağrılarına teslim olmuş ve nefretini unutmuştu. Karnı acıktıkça besleniyordu. Meyvelerin en lezzetlilerini seçiyor, yakaladığı balıkların sağlıksız görünenlerini serbest bırakıyor, ormanda kovaladığı hayvanları dartıyla vurur vurmaz iştahı kaçıyordu" (Sepúlveda, 2017, s. 38).
}

Eserde Bolívar doğaya uyum sağladıkça doğayla bütünleştir ve özgürleştiğini hisseder. Böylelikle Bolívar insan merkezli bakış açısadan kurtulur.

Isabel Allende, Canavarlar Kenti'nde büyükannesi Kate Cold'la beraber Amazonlar'da bulunduğu iddia edilen canavarın peşine düşen Alex'in serüveninde çevre bilincinin önemini vurgulanmıştır. Yolculuk öncesi büyükannesi bilimsel bir derginin Brezilya ve Venezuela arasındaki Amazonlar'ın derinliklerinde birçok kez görülen canavarı aramak üzere yapılacak bir geziyi finanse ettiğini anlatır ve yolculuk bu şekilde başlar (Allende, 2016, s. 49). Gezide yanlarında kibirli antropolog Leblanc, Brezilyalı rehber Carlos Santos ve kızı Nadia, İngiliz fotoğrafçı Timothy Bruce, Venezuelalı doktor Omayra Torres ve birkaç asker vardır. Alex'de Aşk Romanları Okuyan ihtiyar'daki Bolívar gibi yolculuğun öncesinde ve ilk safhasında doğanın 
bozulamaz bütünlügünü anlayamaz ve doğayı ötekileştiren bir tavırla hareket eder. Antropolog Leblanc, Sepúlveda'nın eserindeki belediye başkanı gibi insanlara ve doğaya karşı saygısızca davranan duyarsız bir karakterdir. Eserde Leblanc şu şekilde tanıtılır:

\footnotetext{
“Alex Leblanc'ı beyaz sakallı, etkileyici görünümlü bir bilim adamı olarak hayal etmişti, oysa kısa boylu, sıska, sinirli dudaklarında sürekli bir küçümseme ya da acımasızlık ifadesi taşıyan, fare gibi minicik gözlü, elli yaşlarında ufak tefek bir adamdı. Belinde taşıdığı silahlardan ayaklarındaki ağır botlara ve rengârenk minik tüylerle süslü Avustralya şapkasına varana kadar, her şeyiyle tam filmlerdeki gibi vahşi hayvan avcısı kılığındaydı" (Allende, 2016, s. 56).
}

Amazon bölgesinde yerli kabilelerle bir araya gelen Leblanc'ın yüzeyselliği Sepúlveda'nın eserindeki belediye başkanı gibi eserde yerlilerin dünyanın en "vahşi" varlıkları olduğunu ileri sürmesiyle ortaya çımmaktadır. Yerlileri ötekileştiren ve kendinden başka herkesi önemsizleştiren antropolog ve daha çevre bilinci oluşmamış Alex, yerlilerin gelişmemiş olduklarını okuduğu kitaptan anlatırken büyükannesiyle arasındaki diyalog şu şekilde devam eder:

\begin{abstract}
“Bu kitapta yerlilerin Taş Devri'ndeki gibi yaşadıkları anlatılıyor. Daha tekerleği bile icat etmemişler dedi Alex. Ona ihtiyaçları yok ki. O arazide işlerine yaramaz, taşıyacakları hiçbir şeyleri yok bir yere gitmek için aceleleri de, diye karşılık verdi Kate Cold (...) Yazıyı da bilmiyorlarmış diye ekledi Alex. Herhalde bellekleri iyidir, dedi Kate. Sanat etkinlikleri de yokmuş, yalnızca bedenlerini boyayıp tüylerle süslenirlermiş, diye açıkladı Alex. Onlar ünlü olmaya ya da başkaları arasında sivrilmeye de aldırmazlar. Bizde sanatçı denilenlerin çoğu onları örnek almalı, diye yanıt verdi büyükannesi"(Allende, 2016, s. 54).
\end{abstract}

Sepúlveda'nın Aşk Romanları Okuyan ihtiyar adlı eserinde Bolívar, Shuar yerlilerlerinden ormana dair birçok bilgi edinir; sadeliği ve doğaki dengeyi öğrenir. Bolívar bir süre sonra yerlilerden ayrılarak El Idilio'ya yerleşmeye karar verir (Sepúlveda, 2017, s. 44-48). Sepúlveda, eserin ilerleyen bölümlerinde El Idilio'yu kentleşmeye başlamış bir yerleşim birimi olarak tasvir eder. Yaban hayatın getirdiği doğallığı kaybetmiş hem altın arayıcılarının hem de bilinçsiz yerleşimcilerin buluşma noktasıdır. İnsanların doğaya ve hayvanlara karşı davranışları eserde şu şekilde belirtilir: "Yerleşimciler de altın arayıcıları da ormanda her türlü aptal hatayı işliyorlardı. Düşüncesizce yayılmalarının sonucunda kimi hayvanları durduk yere saldırganlaştırıyorlardı. Bazen birkaç metrecik düz toprak elde etmek için gelişigüzel hendekler kazarak bir boayı yuvasından ediyor, hayvan da bir katırı öldürerek hıncını alıyordu" (Sepúlveda, 2017, s. 49).

Canavarlar Kenti'nde, Alex'in yerlilerle ilk tanışması rehber Carlos Santos'un dokuz yaşındaki kızı Nadia sayesinde gerçekleşir. Yaşlı bir şaman ${ }^{3}$ olan Walimai' yi Nadia sayesinde tanır ve yaşlı şaman vasıtasıyla ormandaki yerlileri tanıma fırsatı yakalar. Walimai eserde Alex ve Nadia'ya yardım eden bir figür olarak okuyucu karşısına çıkar. Tehlikeleri önceden haber verir ve böylece çocukların kötülüklerden korunmasına yardımcı olur. Walimai Alex'in içindeki gücü, başka bir değişle "totem hayvanı" olan panteri ve Nadia'nın içindeki kartal ruhunu da tanımasını sağlar. Alex, Carías'ın yerleşkesinde panterle karşılaşır, bu durum da Alex'in totem hayvanını tetikler. Eserde totem hayvanı kavramı ve onu bulması (içinde hissetmesi) şu şekilde açıklanır: "Hepimizin içinde, bize eşlik eden bir hayvan ruhu vardır. Bizim kendi ruhumuz gibidir bu. Herkes karşılaşamaz kendi hayvanıyla, yalnızca büyük savaşçılar ve şamanlar karşılaşabilirler ama sen aramadan buldun onu. Senin adın Panter" ( Allende, 2016, s. 112).

Alex, kendi içindeki panter ruhunu keşfetmiş böylelikle doğanın bir parçası olduğu gerçeğini de bu olay sayesinde algılamıştır. İlerleyen bölümlerde Alex'in Sis İnsanları olarak 
adlandırılan yerlilerle karşılaşması ve bu süreç içinde Sepúlveda'nın Aşk Romanları Okuyan ihtiyar adlı eserindeki Bolívar gibi yerlileri gözlemlemesiyle onlara duyduğu saygının arttığ görülmektedir. Yerlilerin düşünce tarzını ve doğayla bir yaşamlarını farkeden Alex, başına gelenlere daha geniş bir perspektiften bakmayı da öğrenir. Böylelikle yüzü doğaya dönük ve çevre bilinci yüksek bir yaşama adım atar.

\section{Antonio José Bolívar Proaño ve Alexander Cold'un Ormanın Kalbine Yolculuğu}

Kitapların içinde kaybolarak günlerini geçiren Bolívar'ı, belediye başkanının zorlamasıyla Amazonlar'in derinliklerinde ruhsal ve fiziksel anlamda zorlu bir mücadele beklemektedir. El Idilio'nun biraz dışında yaşayan ve altın arayıcılarına erzak sağlayan bir dükkân açan yerleşimci Miranda'nın katırı yaralı bir şekilde onların bulunduğu tarafa doğru gelir. Bu durum üzerine belediye başkanı, Bolívar'la beraber olayı çözmek için yola çıkmak ister. Öncelikli hedefleri Miranda'nın dükkânına ulaşmaktır. Yollar ekipteki diğer insanlar için uzun ve zorlu olmasına karşın Bolívar dinlenmek için konakladıkları her düzlükte veya güvenli arazide kendini ormanın bir parçasıymış gibi hissetmeye daha da yaklaşır ve fiziksel yolculuğu ruhsal anlamda derinleşir. İlerleyen saatlerde Miranda'nın bakkal dükkânını, yerleşimcinin cesedini ve ikinci bir ceset daha bulurlar. Miranda'yı ve diğer adamı jaguar öldürmüştür. Ekip jaguara gitgide yaklaşmaktadır. Bu yaşanan gerilimli anları fırsat bilen belediye başkanı jaguarı bulması ve öldürmesi karşılığında Bolívar'a belli bir miktar para verileceğini söyler. Bolívar'ın teklifi kabul etmesiyle asıl yolculuk başlar (Sepúlveda, 2017, s. 93-98).

Bolívar her ne kadar jaguarı öldürmeyi kabul etse de içindeki karmaşa devam etmektedir: "İçinden bir ses hayvanın yakınlarda olduğunu söylüyordu. Belki de o sırada kendilerini izliyor ve saldırdığı insanların kendisini nasıl olup da rahat bıraktığını merak etmeye başlıyordu(...) Göze göz dişe diş kanunu, kanlı da olsa kaçınılmazdı" (Sepúlveda, 2017, s. 99). Yerleşimci, jaguarın yavrularını belki de jaguarın eşini de katletmiş olabilirdi. Bolívar korkuyu, merhameti ve empatiyi aynı anda yaşamaktadır. Bu durum da Bolívar'da anlam karmaşasına yol açar. İhtiyar ne yapmalıdır? Nasıl davranmalıdır? Bu durumla başa çıkmakta oldukça zorlanmaktadır. Eserin sonlarına doğu Bolívar dişi jaguarla ilk karşılaşmasında dişi jaguar onu yaralı eşinin yanına götürmüş ve erkek jaguar daha fazla acı çekmesin diye ihtiyarın onu öldürmesini sağlamıştır. Bu durum Bolívar için oldukça sancılıdır, çünkü erkek jaguarı kendi elleriyle öldürmek zorunda kalmıştır (Sepúlveda, 2017, s. 110). Dişi jaguarla ikinci ve son karşılaşması bir önceki karşılaşması gibi hem ruhen hem de fiziksel açıdan oldukça yorucudur, çünkü Bolívar onca yıldır yaşadığı ormana, evine karşı savaşmaktadır. Bolívar uzun bir kovalamacanın ardından dişi jaguarı tüfekle öldürür. Tüfekten çıkan saçmanın jaguarın göğsünü paramparça ettiğini gören ihtiyarın duyguları eserin sonunda şu şekilde aktarılır: “Antonio José Bolívar Proaña yavaşça ayağa kalktı. Jaguarın cesedine yaklaştı ve çiftesinden çıkan saçmaların hayvanı nasıl parçaladığını görünce dehşete düştü. Hayvanın göğsü dev bir kardinal kuşu gibi kıpkırmızıydı (...)" (Sepúlveda, 2017, s. 114). Bu görüntü ve ardından gelen pişmanlık hissi Bolívar'ın hatasının sonucudur. Bolívar'ın zihinsel dönüşümü tam da bu noktada sarsıcı bir şekilde gerçekleşir. Kendine kızarak tüfeğini nehre atar. Kendisinin bu denli açgözlü bir varlığa dönüşmesinden ötürü ağlamaya başlar. Bu duygu yoğunluğu eserde şu şekilde belirtilir: “Takma dişlerini çıkarıp mendiline sarmaladı ve bu trajediyi tetikleyen gringoya, belediye başkanına, altın arayıcılarına, canından çok sevdiği Amazon Ormanı'nın bekâretine göz diken herkese lanet okudu; sonra palasıyla kestiği kalın bir dalı baston gibi kullanarak El Idilio'ya barakasına ve birbirinden güzel sözcüklerle aşktan 
bahsederek insanların ne kadar barbar olduğunu ona unutturan romanlarına doğru yola koyuldu" (Sepúlveda, 2017, s. 115). Bolívar'ın jaguarla karşılaşmasının sonuçları onun açısından oldukça zorlayıcıdır. Bolívar, jaguarla, ormanla ve en önemlisi kendisiyle yüzleşir. Sepúlveda, Bolívar'ın ruhsal anlamda geçirdiği değişimi eser boyunca net ve keskin ifadelerle sunar. Böylelikle insanın doğayla olan ilişkisini yeniden gözden geçirmesini ve sorgulamasını sağlar.

Allende'nin Canavarlar Kenti'nde de Alex'in dönüşümü Aşk Romanları Okuyan ihtiyar adlı eserindeki Bolívar gibi yerlilerle birlikteyken başlar. Eserde bu durum şu şekilde aktarılır:

\footnotetext{
“Hızlı yürüyüş temposu saatler boyu değişmeden sürdü; yalnızca arada bir su içmek için derelerde duruyorlardı. Alex acıktığını hissediyor ama hiç değilse topuğunda karıncanın ısırdığı yerin artık ağrımamasına şükrediyordu. César Santos, yerlilerin ancak fırsat bulduklarında yemek yediklerini anlatmıştı. Bu da her gün olmayabiliyordu. Organizmları enerji depolamaya alışmıştı; oysa kendisinin evdeki buzdolabı her zaman yiyeceklerle tıklım tıklım doluydu. (...) Alışkanlıklarının nasıl tümüyle değiştiğini görünce gülümsemekten kendini alamadı" ( Allende, 2016, ss. 189-190).
}

Alex Amazonlar'ın içine karıştıkça üzerindeki fazla giysilerden, ona ağır gelen düşüncelerden kısacası tüm yüklerinden kurtulmayı öğrenir. Zihinsel anlamda hafifler, doğanın bir parçası olduğunu hisseder ve özgürleşir. Yerliler Alex'in kutsal hayvan olan kara panterin ruhuna sahip olduğunu ve onlara yardıma geldiğine inanırlar. Nadia'nın rüyasında gördüğü üç kristal yumurtayı aramak için El Dorado'ya giderler. Sis İnsanları o yumurtaların kendilerini kurtaracağını düşünmektedirler. Uzun uğraşlar sonucu El Dorado'ya gelen Alex burada dev canavarlarla karşılaşır. Alex'in yanında Nadia ve Walimai vardır. Yaşlı şaman canavarlara kabilenin başından geçen her şeyi anlatır. Bunun yanı sıra yabancıların ormanı istila ettiklerinden de bahseder. Yabancılar El Dorado'yu aramaktadırlar. Yörenin zenginliklerine göz dikmiş Mauro Carías gibi ormanları yok etmek isteyenler; yerliler ve tüm Amazon için çok tehlikelidirler. Alex ve Nadia yabancıların göz diktiği El Dorado'yu insan tahribatından korumalılardır. Bu görevi başarırlarsa, Nadia kristal yumurtaları, Alex ise annesinin iyileşmesi için sağlık suyunu alacaktır. Eserin sonunda, verilen tüm görevleri tamamlayan ve kendi gücünün farkına varan Alex hem El Dorado'yu yabancıların istilasından kurtarmayı başarır hem de büyükannesinin yanında keşif grubuna yerlileri hastalıktan korumak amacıyla aşı yapacağını söyleyen doktor Omayra Torres'in ve sevgilisi Mauro Carías'ın foyasını ortaya çıkarır. Bu yaşadığı olağandışı serüven Alex'in olgunlaşmasına ve zihinsel anlamda dönüşümüne yardımcı olur. Alex'in ekolojik bilinç yolundaki dönüşümü bir hayvanla etkileşimi yoluyla gerçekleşirken, ikinci bahsedilen dönüşüm, bireyin, doğayla uyumlu bir ortak yaşam tarzı benimsemiş diğer insan toplulukları ile etkileşimi sonucunda gerçekleşmektedir. Eserin sonunda Alex ekolojik dengenin önemini kavrar; kendine, doğaya sayg1 ve sevgiyle yaklaşan bir birey haline gelir.

\section{Sonuç}

Yaşadığımız yeryüzü, içinde barındırdığı canlı ve cansız varlıklarla bir bütün olarak evimizdir. Bu nedenle bireyin belki de en önemli görevlerinden biri yaşadığı gezegeni korumaktır. Bu süreçte farkındalık kazanılması gerekmektedir. Farkındalığın oluşumunda insanları çevre sorunları hakkında bilgilendirmek ve daha bilinçli bir hale getirmek açışından edebi anlatılar önemli bir görev üstlenmektedir. Bu çalışmada, ekosistemlerin ve iç dengelerinin, ekosistemdeki (insan ve insan olmayan) canlı çeşitliliğinin korunması ekosistemlerin öneminin kavranması açısından Luis Sepúlveda'nın Aşk Romanları Okuyan 
İhtiyar adlı eseriyle Isabel Allende'nin genç okurlara yönelik yazdığ üçlemenin ilk kitabı Canavarlar Kenti adlı eserinin ekoeleştirel değerlendirilmesi yapılmıştır. Bu bağlamda doğada insan kaynaklı tahribatın yaratacağı olumsuz sonuçlar vurgulanmıştır. Her iki eser öncelikle çevre bilincinin öneminin vurgulanması nedeniyle ortak paydada birleşmektedir. Sepúlveda ve Allende' nin amacı okura doğayla uyum içinde yaşamanın önemini göstermektir. Bolívar'ın ve Alex'in ekolojik bilincinin gelişimi doğadaki dengenin önemi etrafında şekillenir. Doğa içinde gerçekleşen gelişimin ve dönüşümün karakterler üzerindeki yansıması vasıtasıyla da okur, dünya üzerindeki tüm varlıkların kendi öz değerini ve önemini farkeder.

\section{Kaynakça}

Akın, G. (2017). Insan çevre etkileşimi. Ankara: Bilgin Kültür Sanat Yayınları.

Allende, I. (2016). Canavarlar kenti (İ. Kut, Çev.). İstanbul: Can Yayınları.

Araya, Grandón, J, G. (2016) Hacia una mirada ecocrítica de la literatura hispanoamericana. Desde el Sur, 91, ss. 27-38. doi: 10.21142/DES-0901-2017-27-38

Arıkan, A. (2011). Edebi metin çözümlemesi ve ekoeleştiri. Mediterranean Journal of Humanities, 1, 43-51. doi: 10.13114/MJH/20111809

Bookchin, M. (2013). Ekolojik bir topluma doğru. (A. Yılmaz, Çev.). İstanbul: Sümer Yayıncılık. Carson, R. (2011). Sessiz bahar (Ç. Güler, Çev.). Ankara Palme Yayıncılık.

Ergin Zengin, Sezen., (2018). İnsan- merkezciliğin yükselişi: avcı-toplayıcılıktan günümüze hayvanın değişen statüsü. Doğu Batı, 82, 143-161.

Ergin, M., \& Dolcerocca, Ö. N. (2016). Edebiyata ekoeleştirel yaklaşımlar: ekoşiir ve Elif Sofya. SEFAD, 36, 297-314. doi: 10.21497/sefad.285241

Garrad, G. (2016). Ekoeleştiri ekoloji ve çevre üzerine kültürel çalışmalar. (E. Genç, Çev.). İstanbul: Kolektif Kitap.

Glotfelty, C. (1996). Introduction. Literary Studies in an Age of Environmental Crisis. Glotfelty, Ch. ve Fromm, H. (Eds.), The Ecocriticism Reader. Landmarks in Literary Ecology içinde. Athens ve London: The University of Georgia Press, xv-xxxvii.

Heffes, G. (2014). Introducción. Para una ecocrítica latinoamericana: entre la postulación de un ecocentrismo crítico y la crítica a un antropocentrismo hegemónico, Revista de Crítica Literaria Latinoamericana, 40, 79 ss. 11-34. Erişim adresi: https://www.jstor.org/stable/pdf/43854807.pdf

Keleş, R. (2015). 100 soruda çevre: çevre sorunları ve çevre politikası. İzmir: Yakın Kitapevi Yayınları.

Kışlalığlu, M.,\& Berkes, F. (2017). Çevre ve ekoloji. İstanbul: Remzi Kitapevi.

Oppermann, S. (2012). Ekoeleştiri: çevre ve edebiyat çalışmalarının dünü ve bugünü. S.

Oppermann (Ed). Ekoeleştiri çevre ve edebiyat içinde (s. 9-58). Ankara: Phoenix Yayınevi.

Örnek, S. V., (2014). 100 soruda ilkellerde din, büyü, sanat, efsane. Ankara: Bilgesu

Özdağ, U. (2017). Çevreci eleştiriye giriş doğa kültür edebiyat. Ankara: Ürün Yayınları.

Rueckert, W. (1996). Literature and ecology. C. Glotfelty-H. Fromm (Eds.), The Ecocriticism Reader: Landmarks in Literary Ecology içinde (s.105-123). Athens: Georgia UP.

Sepúlveda, L. (2017). Aşk romanları okuyan ihtiyar (E. İmre, Çev.). İstanbul: Can Yayınları.

Sepúlveda, L., \& Petrini, Carlo. (2018). Mutluluğa dair bir düşünce (Ş. Gezgin, Çev.). İstanbul: Can Yayınları.

Toska, S. (2017). Ekokurgu: ekolojik sorunların çözüm yolu olarak edebiyat. İstanbul: Yeni İnsan Yayınevi. 
Yazgünoğlu, K. C., (2018). İnsan çağında çevresel estetik: güzelin ve çirkinin ötesinde “doğasonrası" ekolojiler. Doğu Batı, 83, 67-85.

\section{Açıklamalar}

1 Latin Amerika Edebiyatı'nın ekoeleştirel değerlendirilmesi için bkz. Gisela Heffes, Introducción. Para una ecocrítica latinoamericana: entre la postulación de un ecocentrismo crítico y la crítica a un antropocentrismo hegemónico, Revista de Crítica Literaria Latinoamericana, 40, 79, ss. 11-34, https://www.jstor.org/stable/pdf/43854807.pdf; ayrica bkz: Juan Gabriel Araya Grandón, Hacia una mirada ecocrítica de la literatura hispanoamericana, Desde el Sur, 9, 1, ss. 27-38 I DOI: 10.21142/DES-0901-2017-27-38

2 Sepúlveda, 1978 yılında Ekvador'da Amazon Havzası'na yolculuğunda 7 ay boyunca Shuar adlı yerli kabileyle yaşamıştır ve Shuarlar yerlilerinden doğaya dair pek çok şey öğrenmiştir. Sepúlveda'nın çevre bilincinin gelişmesinde bu olay onun için önemli bir dönüm noktasıdır (Sepúlveda ve Petrini, 2018).

${ }^{3}$ Şamanizm hakkında detaylı bilgi için bkz. Sedat Veyis Örnek, (2014) 100 soruda ilkellerde din, büyü, sanat, efsane. Ankara: Bilgesu (s. 48-68). 